Krzysztof TROJNAR, dr hab. inż. prof. PRz

Politechnika Rzeszowska

ktrojnar@prz.edu.pl

ORCID: 0000-0002-4550-4670

\title{
BEZPIECZEŃSTWO NASYPÓW Z ANTROPOGENICZNYM WYPELNIENIEM GUMOWYM Z RECYKLINGU OPON
}

\begin{abstract}
Streszczenie
W artykule wskazano problemy recyklingu zużytych opon samochodowych i przedstawiono propozycje wykorzystania gumy $\mathrm{z}$ opon do budowy lekkich nasypów zwierających antropogeniczną zasypkę gumową. Przeprowadzono własne analizy na modelach numerycznych nasypu drogowego podpartego ścianami oporowymi, a uzyskane wyniki porównano z wariantem zasypki z piasku. Obliczenia różnych zasypek zawierających rozdrobnione opony pozwoliły wskazać optymalny sposób wykonania nasypu zawierającego gumę $\mathrm{z}$ opon, spełniającego te same wymagania jak rozwiązanie tradycyjne. Pomimo, że zaproponowana antropogeniczna zasypka gumowa jest obecnie droższa od tradycyjnej zasypki z piasku, można wykazać jej przydatność, szczególnie w przypadku słabego podłoża. Przeprowadzona analiza ekonomiczna pokazała korzystną $\mathrm{z}$ punktu widzenia ochrony środowiska strukturę kosztów materiałowych lekkich nasypów $\mathrm{z}$ gumą $\mathrm{w}$ porównaniu $\mathrm{z}$ rozwiązaniem tradycyjnym $\mathrm{z}$ piasku. Wyniki obliczeń odniesiono do budowy przykładowego nasypu na dojeździe do wiaduktu w ciągu drogi DK9 k/Rzeszowa.
\end{abstract}

Słowa kluczowe: ściana oporowa, nasyp drogowy, zużyte opony.

\section{SAFETY OF EMBANKMENTS WITH ANTHROPOGENIC A RUBBER FILLING MADE OF RECYCLED TYRES}

\begin{abstract}
Summary
The article indicates current problems of recycling of used car tyres and presents proposals of using rubber from tyres to build light embankments containing anthropogenic rubber backfill. Our own analyses were carried out on numerical models of road embankment supported by retaining walls, and the obtained results were compared with the variant of sand backfill. Calculations of various backfills containing shredded tires allowed us to indicate the optimal method of making the embankment containing rubber from tires, meeting the same requirements as the traditional solution. Although the proposed anthropogenic rubber backfill is currently more expensive than traditional sand backfill, its usefulness can be demonstrated, especially in the case of weak soil, due to the low settlement of the embankment and high stability, without the need to reinforce the native soil. The economic analysis showed the structure of material costs of light rubber embankments in comparison with the traditional sand solution. The results were related to the construction of an exemplary embankment at the access road to the viaduct along the DK9 road near Rzeszów, Poland.
\end{abstract}

Key words: retaining wall, road embankment, used tires. 


\section{Wprowadzenie}

Według prowadzonych statystyk rocznie w krajach Unii Europejskiej potrzebna jest utylizacja lub zagospodarowanie około 3,5 mln ton zużytych opon samochodowych, z czego około 500 tys. ton przypada na Polskę. Biorąc pod uwagę stale rozwijający się przemysł motoryzacyjny, można przewidywać, że w kolejnych latach liczba zużytych opon będzie rosła. Utylizacja takich tzw. "trudnych" odpadów stanowi już teraz poważny problem społeczny i techniczny w wielu krajach, ponieważ wpływa negatywnie na stan środowiska naturalnego. Mimo obowiązku utylizacji i zakazu składowania całych opon, spora ich część trafia na nielegalne wysypiska lub jest porzucana np. w lasach. Z punktu widzenia zagospodarowania zużytych opon w krajach europejskich największe znaczenia mają trzy dyrektywy unijne: Landfill 1999/31/EC oraz End-of-Life Vehicle 2000/53/EC, Waste Incineration 2000/73/EC. Dotyczą one zakazu składowania zużytych opon i nakładają na kraje UE obowiązek ich odzysku i recyklingu, docelowo na poziomie $85 \%$. W związku z tym wszystkie stare pojazdy przed złomowaniem muszą mieć zdjęte opony, a cementownie wykorzystujące dotąd zużyte opony jako alternatywne paliwo są zobowiązane do wprowadzenia wyższych limitów ograniczania emisji szkodliwych gazów odlotowych. Aktualnie w Polsce odzysk i recykling opon jest jeszcze na niewystarczającym poziome. Wprowadzono już w życie zakaz składowania zużytych opon samochodowych (Ustawa o odpadach z 27 kwietnia 2001r.) oraz nałożono na producentów i importerów pojazdów obowiązek zagospodarowania zużytych opon (Ustawa z 11 maja 2001 r.). W celu szybszego osiągnięcia docelowego poziomu recyklingu opon (85\%) wprowadzono opłaty produktowe i depozytowe. Obecnie poszukuje sie różnych sposobów zagospodarowania zużytych opon w innowacyjnych konstrukcjach (Bielańska 2016, Duda i Trojnar 2016, Duda 2017, Meei-Hoan Ho et al. 2010, 2011). Zużyte opony mogą podlegać wykorzystaniu w jednej z trzech możliwych form recyklingu: produktowego, materiałowego lub energetycznego. Jedną z pro-ekologicznych metod utylizacji opon jest ich powtórne wykorzystanie jako rozdrobnionego składnika antropogenicznych zasypek przy budowie konstrukcji oporowych i nasypów (Hennebert et al. 2014). Rozdrabnianie opon jest już stosowane na skalę przemysłową w krajach zachodnich w celu uzyskania materiału przydatnego do dalszego wtórnego wykorzystania (Gronowicz i Kubiak, 2007, Sybilski 2019). Proces ten polega na cięciu opon w sposób mechaniczny albo na kruszeniu metodą kriogeniczną z zastosowaniem ciekłego azotu. W końcowej fazie oddziela się frakcje gumowe od stalowych i tekstylnych. $\mathrm{W}$ efekcie rozdrobnienia opon otrzymuje się mieszankę składającą się z gumy, tekstyliów oraz (opcjonalnie) części metalowych. Sposób wykorzystania rozdrobnionej gumy w budownictwie zależy w dużej mierze od wielkości cząstek. Klasyfikację materiałów otrzymywanych ze zużytych opon opartą na przepisach europejskich podano w tab. 1 (EN 14243, 2005). Przykładowe formy przetworzonych opon w postaci strzępów gumowych pokazano na rys. 1. Strzępy z opon mogą być z powodzeniem stosowane do budowy nasypów jako lekkie antropogeniczne kruszywo oraz jako zasypka konstrukcji oporowych, ścian tuneli oraz przyczółków mostowych. Ten rodzaj niekonwencjonalnego materiału spełnia też definicję gruntu antropogenicznego (Drągowski, 2010). Przydatność materiałowa części gumowych pochodzących z przetworzenia opon wynika przede wszystkim z korzystnych właściwości fizycznych, ponieważ mają trzykrotnie mniejszy ciężar objętościowy w porównaniu ze standardowymi kruszywami mineralnymi, ośmiokrotnie lepszą izolacyjność cieplną oraz bardzo dobre właściwości drenujące wodę. Wywołują przy tym mniejsze parcie boczne oraz mogą pełnić rolę warstw tłumiących drgania. Te właściwości są szczególnie pożądane w materiałach stosowanych w budownictwie komunikacyjnym (Oikonomou i Mavridou, 2009), Shrestha et al. 2016). 
Tabela 1. Europejska klasyfikacja rozdrobnionych opon

\begin{tabular}{|l|c|}
\hline \multicolumn{1}{|c|}{ Rodzaj rozdrobnionych odpadów gumowych } & Rozmiar cząstek [mm] \\
\hline Opony cięte (połówki i mniejsze fragmenty) & $>300$ \\
\hline Strzępy (shreds) & $50 \div 300$ \\
\hline Czipsy (chips) & $10 \div 50$ \\
\hline Granulat (granulate) & $1 \div 10$ \\
\hline Miał (powder) & $0 \div 1$ \\
\hline
\end{tabular}
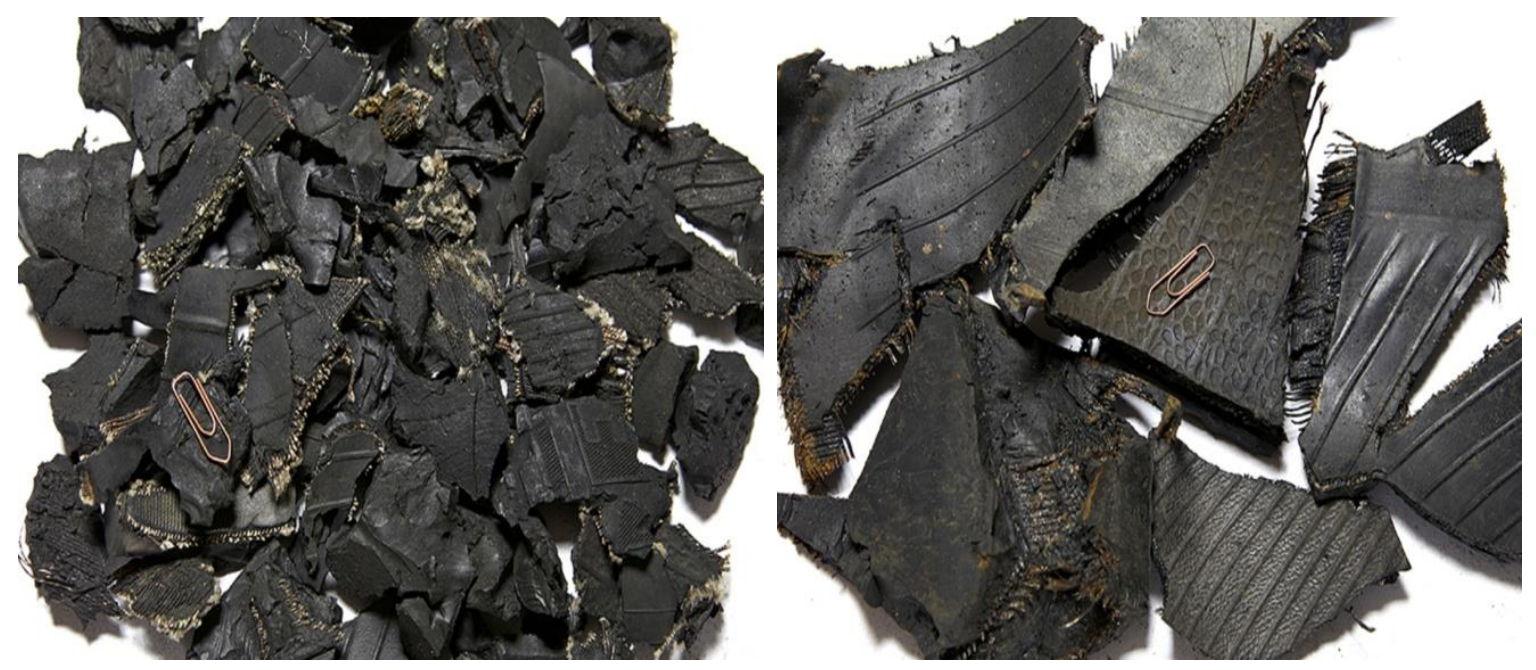

Rys. 1. Formy rozdrobnionych opon przydatne do wypełnienia nasypów;

a. czipsy, b. strzępy

\section{Antropogeniczne zasypki gumowe do budowy nasypów i konstrukcji oporowych}

\section{Opis przykladowego nasypu}

Analizowanym przykładowym obiektem jest nasyp w ciągu drogi krajowej DK9, stanowiący dojazd do wiaduktu nad drogą wojewódzką nr 869 na północ od Rzeszowa. Skrzyżowanie zaprojektowano jako dwupoziomowe w formie węzła WB typu „karo”. Widok ogólny obiektu pokazano na rys. 2.

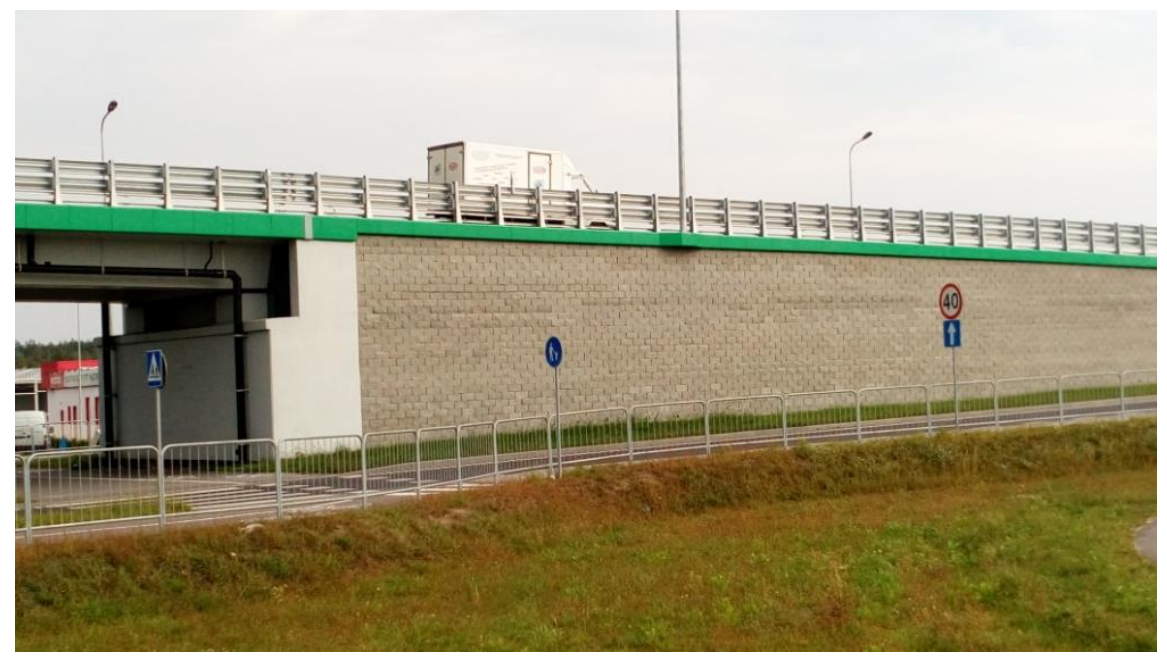


Rys. 2. Nasyp na dojeździe do wiaduktu w ciągu drogi DK9 k/Rzeszowa

Wiadukt ma długość $80 \mathrm{~m}$. Droga na nasypie jest dwujezdniowa o szerokości 8,40 m. Nasyp ma zmienną wysokość $1-6 \mathrm{~m}$. Wykonano go w formie konstrukcji oporowej w technologii Optem-BLOK. Po obu stronach dojazdu do wiaduktu na dolnym poziomie są dodatkowe jezdnie drogowe, stąd pionowe ściany nasypu zostały podparte konstrukcjami oporowymi i zwieńczone górą gzymsem żelbetowym, na którym zamontowano bariery energochłonne i oświetlenie drogi. Własne analizy obliczeniowe przeprowadzono dla nasypu w przekroju drogowym o wysokości $5.30 \mathrm{~m}$ (w pobliżu przyczółków).

\section{Warunki gruntowo-wodne}

$\mathrm{Na}$ podstawie danych z badań geologicznych ustalono, że podłoże nasypu ma poziomy układ warstw i jest wystarczająco nośne. Korpus nasypu wraz z podpierającymi ścianami oporowymi jest posadowiony na osadach fluwioglacjalnych, interglacjalnych i glacjalnych. Pierwszą 3-metrową warstwę stanowią piaski drobne i pylaste w stanie średniozagęszczonym. Niżej zalegają iły pylaste w stanie plastycznym o miąższości 2,80 m, oparte na glinach lodowcowych w stanie twardoplastycznym. Poziom zwierciadła wód gruntowych jest na głębokości 1,50 m ppt. Parametry geotechniczne warstw podłoża zestawiono $\mathrm{w}$ tab. 2, porządkując je w pakiety warstw obliczeniowych według kryterium stanu gruntu.

Tabela 2. Parametry geotechniczne podłoża

\begin{tabular}{|c|c|c|c|c|c|}
\hline Rodzaj gruntu: & $\mathbf{P} \pi$ & Pd & $\mathbf{I} \pi$ & $\mathrm{I} \pi / \mathrm{P} \pi$ & Gpz \\
\hline \multirow{2}{*}{ Miąższość warstwy, m } & \multicolumn{2}{|c|}{3,0} & \multicolumn{2}{|c|}{2,8} & \multirow{2}{*}{$>10$} \\
\hline & 0,7 & 2,3 & 1,3 & 1,5 & \\
\hline St. zagęszczenia/plastyczności, - & \multicolumn{2}{|c|}{0,35} & \multicolumn{2}{|c|}{0,1} & 0,2 \\
\hline Gęstość objętościowa, kN/m3 & \multicolumn{2}{|c|}{19,0} & \multicolumn{2}{|c|}{19,7} & 21,5 \\
\hline Moduł ściśliwości, MPa & \multicolumn{2}{|c|}{46} & \multicolumn{2}{|c|}{34} & 29 \\
\hline Kąt tarcia wewnętrznego, ${ }^{\circ}$ & \multicolumn{2}{|c|}{29} & \multicolumn{2}{|c|}{12} & 14 \\
\hline Spójność, kPa & \multicolumn{2}{|c|}{0} & \multicolumn{2}{|c|}{57} & 16 \\
\hline
\end{tabular}

\section{Parametry zasypek}

Do analiz obliczeniowych przyjęto zasypkę antropogeniczną ze strzępów gumowych 50/76 oraz porównawczo, tradycyjną zasypkę z piasku średniego (praktycznie wykorzystywana na budowie tego nasypu). Parametry techniczne strzępów gumowych jako alternatywnego materiału do budowy nasypów przyjęto na podstawie badań innych autorów (Edeskär, 2004, Balunaini et al. 2009) i zestawiono w tab. 3, łącznie z parametrami dla piasku.

Tabela 3. Parametry techniczne zasypki z piasku oraz ze strzępów gumowych

\begin{tabular}{|c|c|c|}
\hline Materiał zasypki & $\begin{array}{c}\text { Piasek } \\
\text { średni }\end{array}$ & $\begin{array}{c}\text { Strzępy gumowe } \\
\mathbf{5 0 / 7 6}\end{array}$ \\
\hline Wskaźnik zagęszczenia & 0.98 & 0.98 \\
\hline Ciężar objętościowy, kN/m3 $^{\text {Kąt tarcia wewnętrznego, }}{ }^{\circ}$ & 17.8 & 6.13 \\
\hline Kar & 37 & 19 \\
\hline
\end{tabular}




\begin{tabular}{|c|c|c|}
\hline Spójność, $\mathrm{kPa}$ & 0 & 11.5 \\
\hline Współczynnik Poissona, - & 0.25 & 0.30 \\
\hline Współczynnik filtracji, cm/s & $1.8 \times 10^{-2}$ & 4.8 \\
\hline Moduł sprężystości, MPa & 170 & 1.13 \\
\hline
\end{tabular}

\section{Analiza numeryczna nasypu z wypełnieniem gumowym}

Opracowano trzy warianty modelu numerycznego nasypu podpartego ścianami oporowymi o wysokości $3 \mathrm{~m}, 6 \mathrm{~m}$ i $9 \mathrm{~m}$, przyjmując we wszystkich przypadkach standardowo warunki brzegowe oraz dyskretyzację siatki MES. W strefach styku zasypki ze ścianami oporowymi odpowiednio zagęszczono siatkę w celu uzyskania dokładniejszych wyników. Obszar obliczeniowy MES o wymiarach $40 \mathrm{~m}$ x $20 \mathrm{~m}$ jest pokazany na rys. 3. Przyjęto sprężysto-plastyczny model podłoża oraz zasypki z kryterium plastyczności Coloumba Mohra. Obliczenia wykonano z uwzględnieniem wymagań normowych nośności podłoża i stateczności budowli (PN-EN 1997-1, 2010). Zgodnie z zaleceniami literaturowymi (Youwai i Bergado, 2004) uwzględniono wymaganie, aby maksymalna miąższość jednolitej warstwy odpadów gumowych w nasypie nie przekraczała $3 \mathrm{~m}$ ze względu na ryzyko wystąpienia reakcji termicznych. Wyniki obliczeń pokazały, że niezależnie od wysokości analizowanych nasypów zastosowanie zasypki z rozdrobnionej gumy pozwoliło poprawić ich stateczność. Zestawienie wyników pokazano graficznie na rys. 4 i rys. 5. Obliczone współczynniki bezpieczeństwa na przesuw po gruncie oraz na obrót okazały się wyższe $\mathrm{w}$ porównaniu $\mathrm{z}$ tradycyjnym wypełnieniem $\mathrm{z}$ piasku. Można stąd wysunąć generalny wniosek, że w zakresie wysokości nasypów 3 - 9 m konstrukcje oporowe w których wykorzystano rozdrobnione opony są bardziej stateczne $\mathrm{w}$ porównaniu $\mathrm{z}$ nasypami wykonanymi z piasku.

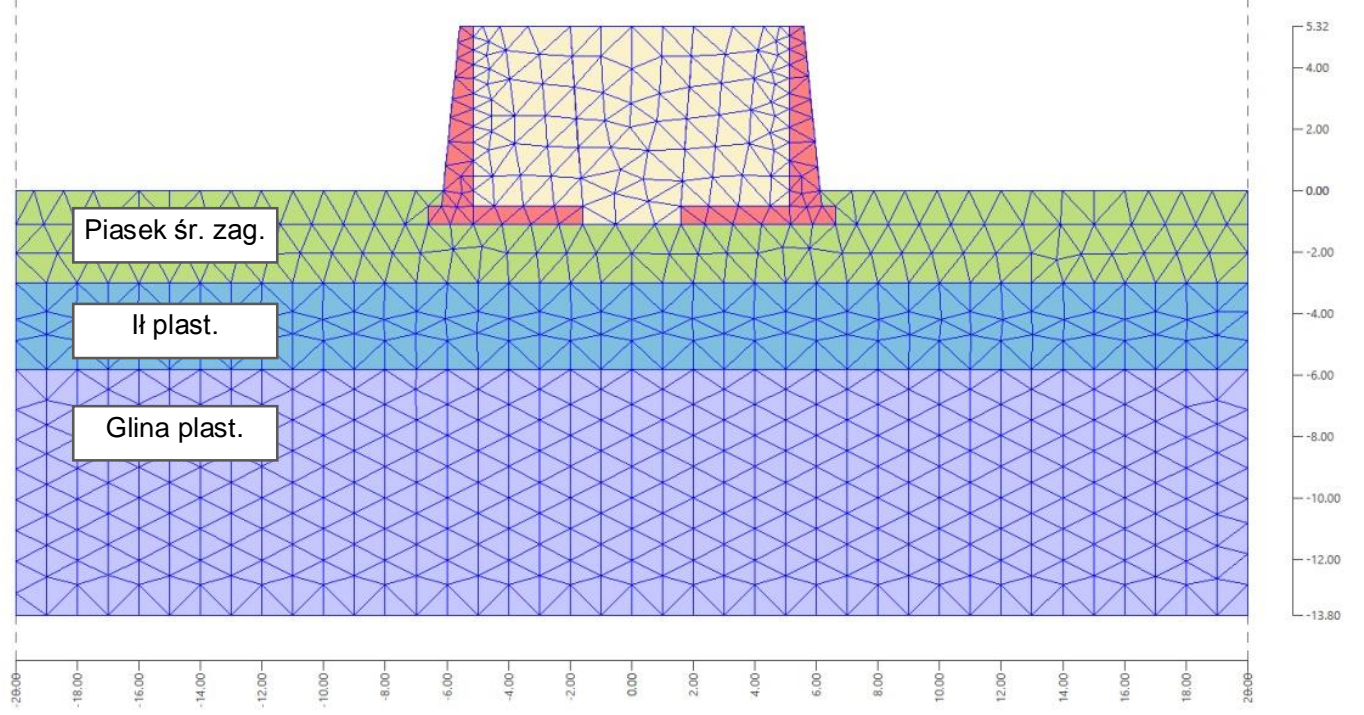

Rys.3. Model numeryczny nasypu

Szczegółowym obliczeniom podano nasyp o wysokości $5.3 \mathrm{~m}$ podparty ścianami płytowo-kątowymi. Wymiary przekroju ścian podpierających przyjęto na podstawie wstępnych obliczeń. Celem analiz było poszukiwanie optymalnego sposobu ułożenia zasypki, który pozwoliłby uzyskać maksymalne korzyści wynikające $\mathrm{z}$ zalet antropogenicznego materiału $\mathrm{z}$ rozdrobnionych opon, przy jednoczesnym zminimalizowaniu zużycia gumy. Wyniki analiz porównano z rozwiązaniem tradycyjnym z użyciem piasku. Rozpatrzono cztery warianty zasypek, różniące się sposobem ich wbudowania w nasyp za konstrukcją oporową. Schematy ułożenia zasypek pokazano na rys. 6 i opisano w tab. 4. 


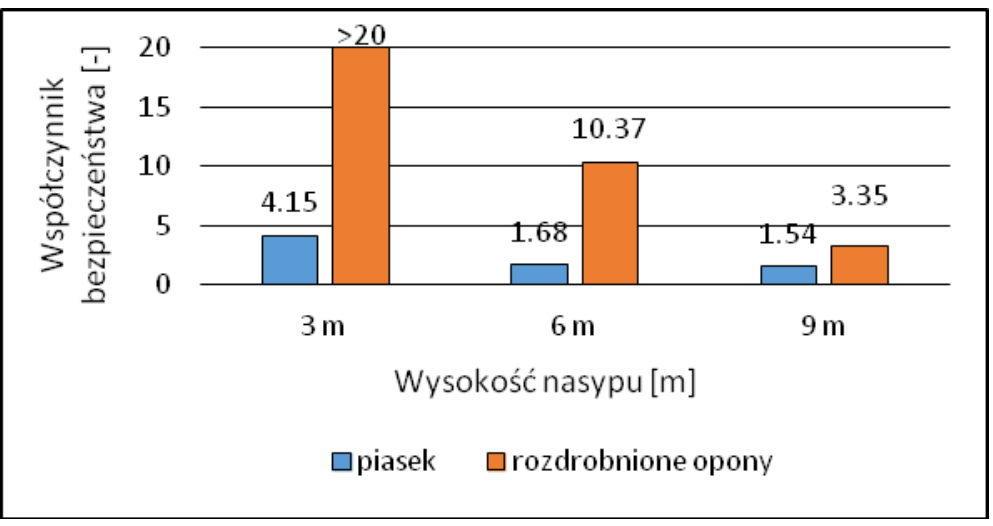

Rys.4. Stateczność na przesuw nasypu o różnej wysokości

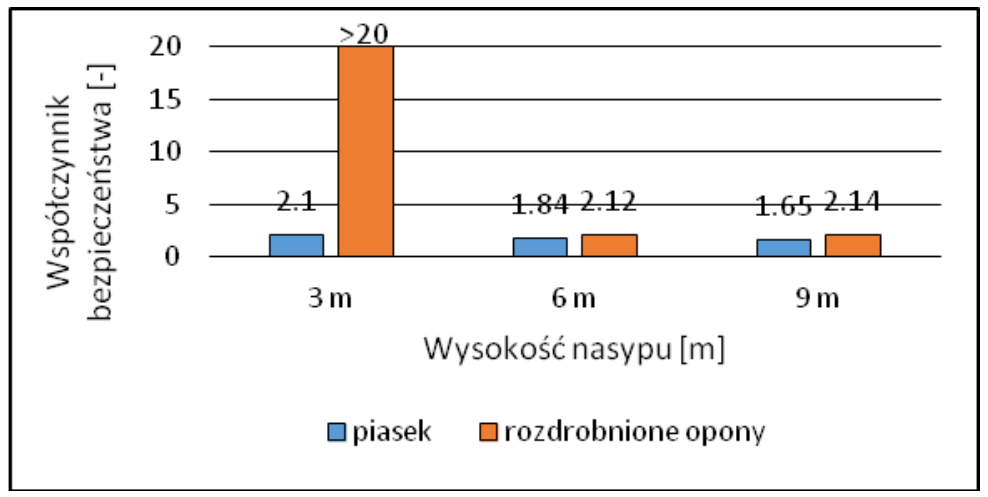

Rys. 5. Stateczność na obrót nasypu o różnej wysokości
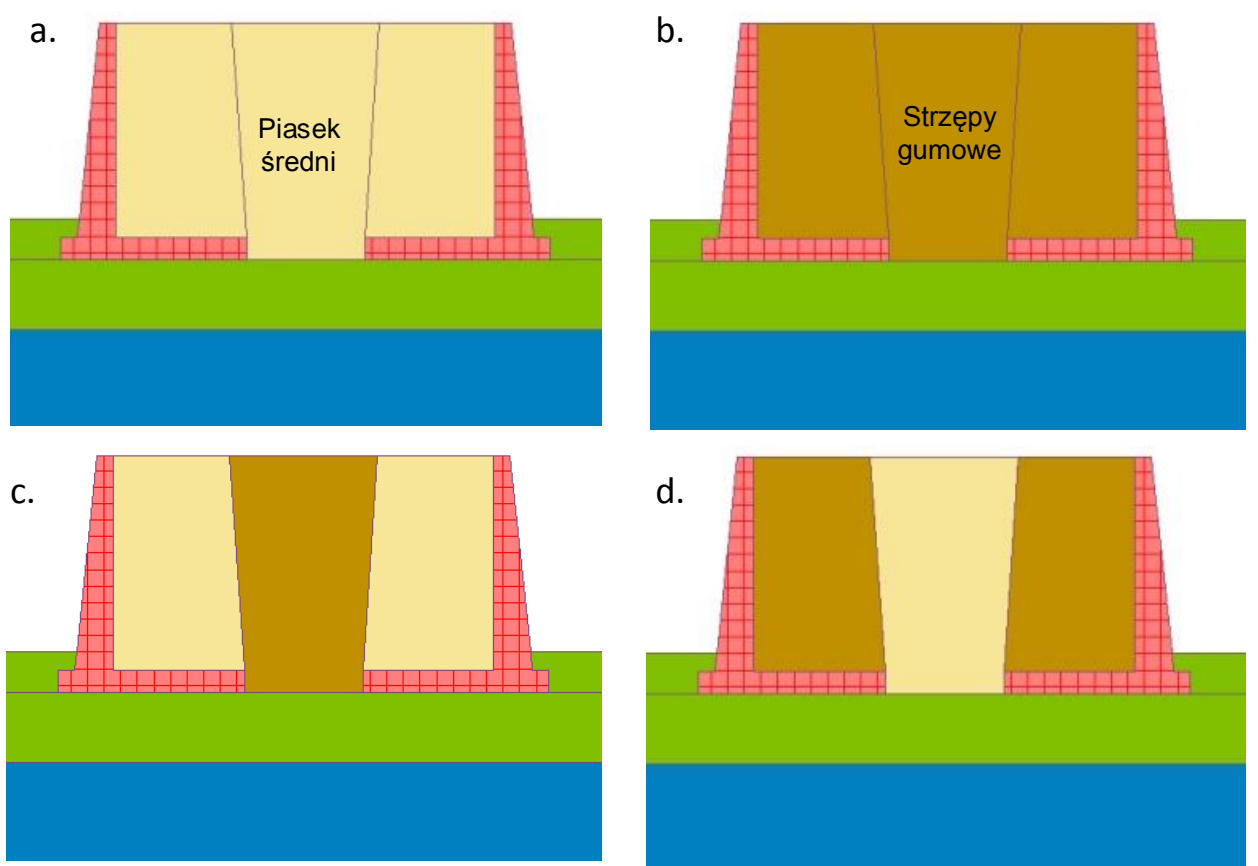

Rys. 6. Analizowane warianty wypetnienia nasypu $(A, B, C, D)$ 
Tabela 4. Analizowane warianty wypełnienia nasypu

\begin{tabular}{|c|l|}
\hline Wariant & \multicolumn{1}{|c|}{ Sposób wypełnienia } \\
\hline Zasypka A & piasek w całym nasypie (wariant porównawczy, rozwiązanie tradycyjne) \\
\hline Zasypka B & strzępy gumowe w całym nasypie \\
\hline Zasypka C & piasek nad odsadzkami, środek nasypu wypełniony strzępami gumowymi \\
\hline Zasypka D & strzępy nad odsadzkami, środek wypełniony piaskiem (odwrotnie do C) \\
\hline
\end{tabular}

Efektem o analiz obliczeniowych MES są wartości naprężeń i odkształceń w podłożu oraz w zasypce pokazane na rys. 7. Przy wyborze najkorzystniejszego wariantu wypełnienia nasypu z użyciem zasypek $\mathrm{z}$ gumą brano pod uwagę: maksymalne naprężenie poziome na ścianę oporową, maksymalne osiadanie nasypu oraz odkształcenie podłoża i naprężenia w strefach pod fundamentem ścian podpierających nasyp. Jako wariant porównawczy przyjęto nasyp z tradycyjnym wypełnieniem z piasku (zasypka A). Wariant z zasypką B (strzępy gumowe na całej szerokości nasypu) okazał się najbardziej korzystny spośród analizowanych wariantów ze względu na znaczące zmniejszenie naprężeń pionowych i prawie dwukrotne zmniejszenie osiadań nasypu. Za pewną wadę tego rozwiązania można uznać stosunkowo duży koszt użycia rozdrobnionej gumy $\mathrm{z}$ opon $\mathrm{w}$ porównaniu $\mathrm{z}$ tą samą objętością piasku w rozwiązaniu tradycyjnym (zasypka A).
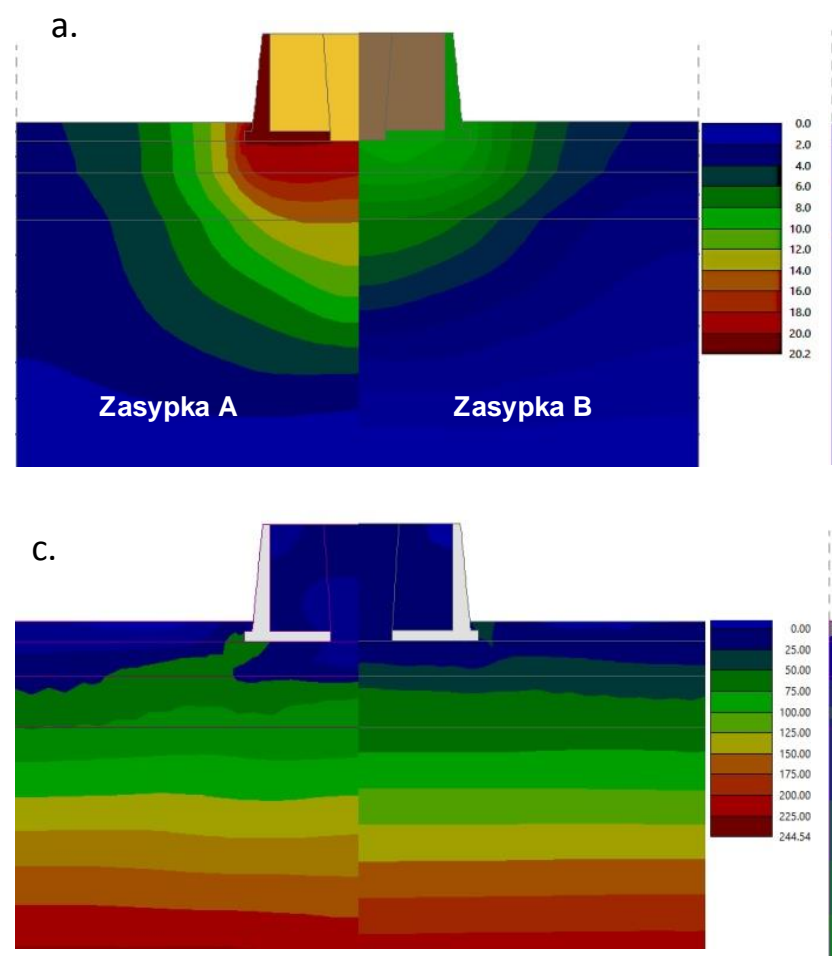
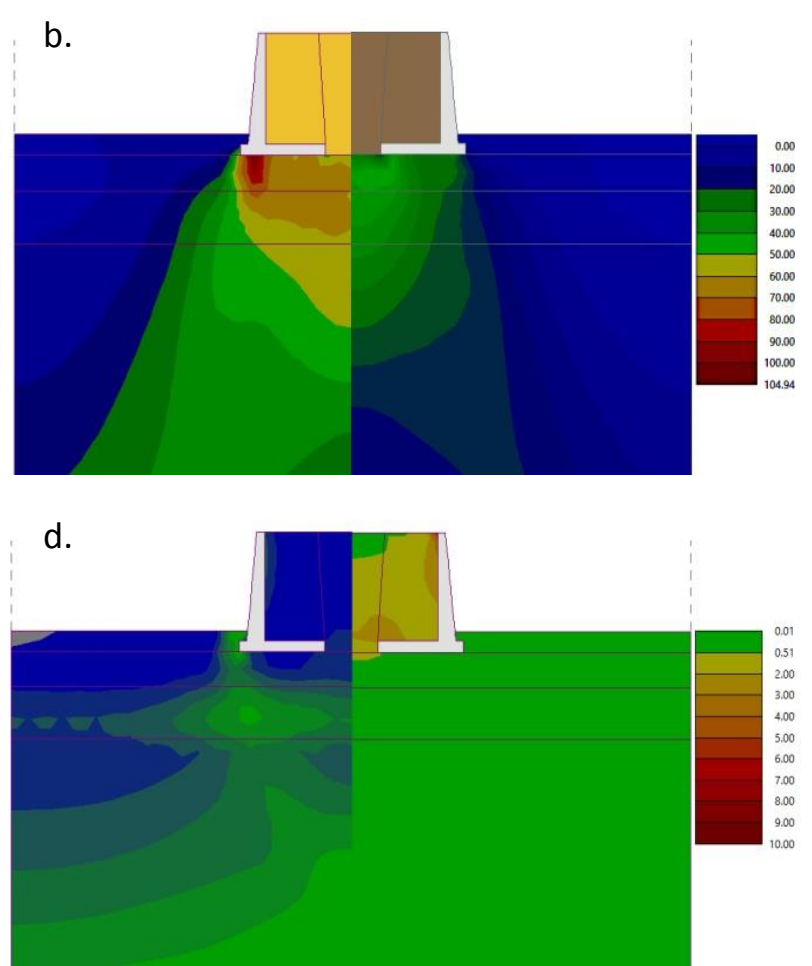

Rys. 7. Porównanie wyników analiz numerycznych nasypu z wypełnieniem tradycyjnym (zasypka A) i gumowym (zasypka B); a. osiadanie, b. naprężenia pionowe, c. naprężenia poziome, d. odkształcenia.

Stwierdzono też, że odkształcenia gumowego wypełnienia nasypu są o $2 \%$ większe niż w przypadku zasypki z piasku. Można to wyeliminować w sposób technologiczny, stosując dodatkowo przewarstwienia z piasku i zagęszczanie warstw strzępów gumowych (Edeskär, 
2004, Glinicka, 2010). Obliczenia pozostałych wariantów pokazały, że w przypadku zasypek C i D wystąpił dość niekorzystny rozkład nacisku na podłoże pod nasypem. Dotyczyło to szczególnie strefy pod fundamentami ścian oporowych (zasypka C) i pod środkiem nasypu (zasypka D). W przypadku nasypu z gumą naprężenia pod krawędzią fundamentu ściany oporowej są o $2 / 3$ mniejsze, a pod środkiem nasypu o $1 / 3$ mnisze w porównaniu $\mathrm{z}$ nasypem $\mathrm{z}$ piasku. Zbiorcze zestawienie wybranych wyników obliczeń dla zasypek A i B przedstawiono na rys. 8 .

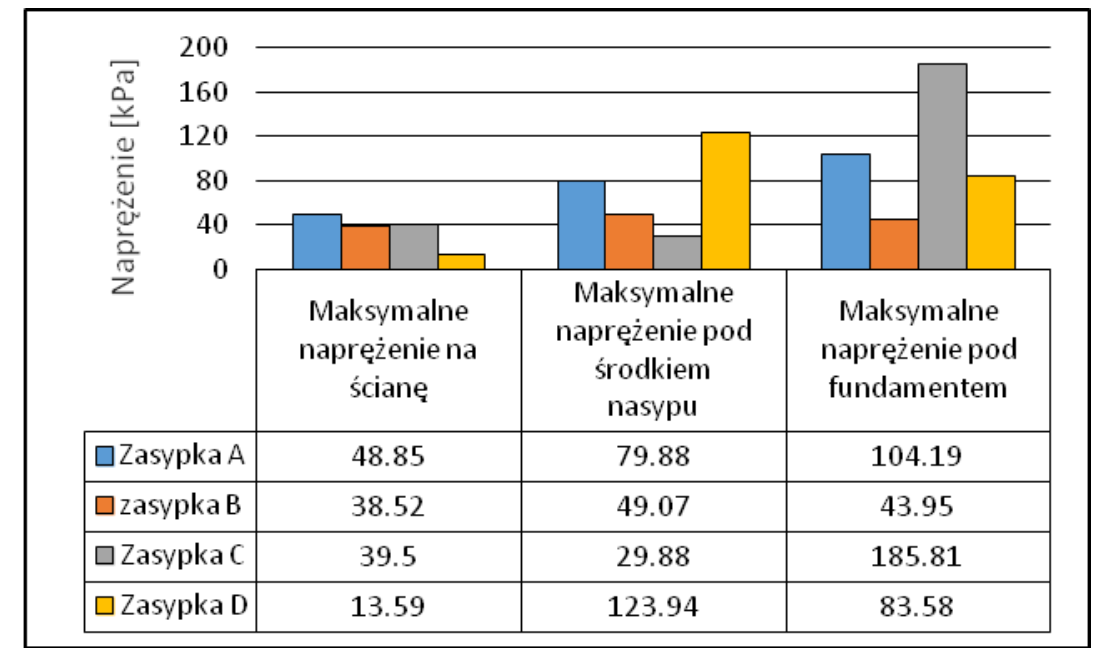

Rys. 8. Wyniki obliczeń dla różnych wariantów wypetnienia nasypów

\section{Analiza ekonomiczna}

W celach porównawczych zestawiono koszty materiałów potrzebnych do budowy nasypu według wariantu tradycyjnego (zasypka A) oraz wariantu alternatywnego z zasypką antropogeniczna ze strzępów gumowych (zasypka B). Przy bezpośrednich porównaniach dwóch różnych rozwiązań materiałowych stosowano znormalizowane wymiary ścian oporowych, przyjęte odpowiednio do obliczonych wartości naprężeń. W obliczeniach przyjęto aktualne ceny brutto materiałów budowlanych, a łączne koszty budowy uśredniono w przeliczeniu na $1 \mathrm{mb}$ długości nasypu. Cenę strzępów opon przyjęto na podstawie danych uzyskanych od polskiego producenta $\mathrm{z}$ firmy J\&B Recykling (J\&B, 2016). W tab. 5 zestawiono ilości materiałów obliczone dla obu wariantów nasypów i ich koszty. Porównanie kosztów przedstawiono graficzne na rys. 9 i 10.

Tabela 5. Koszty materiałowe nasypu tradycyjnego z piasku i z alternatywnego z gumą

\begin{tabular}{|c|c|c|c|c|}
\hline Materiał & Ilość & Cena jedn. & $\begin{array}{c}\text { Koszty materiałowe } \\
{[\mathrm{z} \nmid]}\end{array}$ & $\begin{array}{c}\text { Łączny koszt } \\
1 \mathrm{mb} \text { nasypu [tys. zł] }\end{array}$ \\
\hline \multicolumn{5}{|c|}{ Zasypka A - nasyp tradycyjny z piasku } \\
\hline Zbrojenie & 10 szt. $\phi 20$ & $7,90 \mathrm{zt} / \mathrm{mb}$ & $6,42 \cdot 10 \cdot 7,90=507,20$ & \multirow{3}{*}{7.80} \\
\hline Beton & $13.8 \mathrm{~m}^{3}$ & $301.40 \mathrm{zł} / \mathrm{t}$ & $13,8 \cdot 301,40=4164,70$ & \\
\hline Piasek & $61,8 \mathrm{~m}^{3}$ & $28,30 \mathrm{zt} / \mathrm{t}$ & $61,8 \cdot 1,78 \cdot 28,30=3112,10$ & \\
\hline \multicolumn{5}{|c|}{ Zasypka B - nasyp alternatywny z gumą z opon } \\
\hline Zbrojenie & 12 szt. $\phi 16$ & $4,95 \mathrm{zt} / \mathrm{mb}$ & $6,42 \cdot 12 \cdot 4,95=381,40$ & \multirow{3}{*}{9.96} \\
\hline Beton & $11.0 \mathrm{~m}^{3}$ & $301.40 \mathrm{z} \nmid / \mathrm{t}$ & $11,0 \cdot 301,40=3314,90$ & \\
\hline Piasek & $9.3 \mathrm{~m}^{3}$ & $28.30 \mathrm{zt} / \mathrm{t}$ & $9,3 \cdot 1,78 \cdot 28,30=466,80$ & \\
\hline
\end{tabular}




\begin{tabular}{|l|c|c|c|c|}
\hline Strzępy gum. & $52.5 \mathrm{~m}^{3}$ & $180 \mathrm{zt} / \mathrm{t}$ & $52,5 \cdot 0,613 \cdot 180,00=5796,20$ & \\
\hline
\end{tabular}

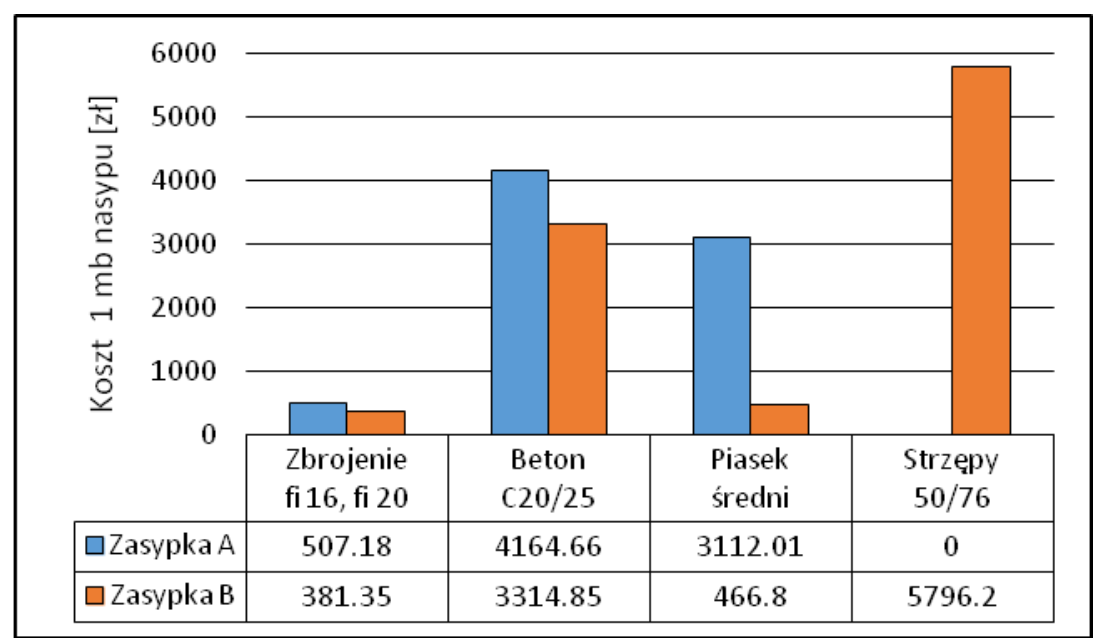

Rys. 9. Porównanie kosztów materiałowych nasypu z zasypką A i B.
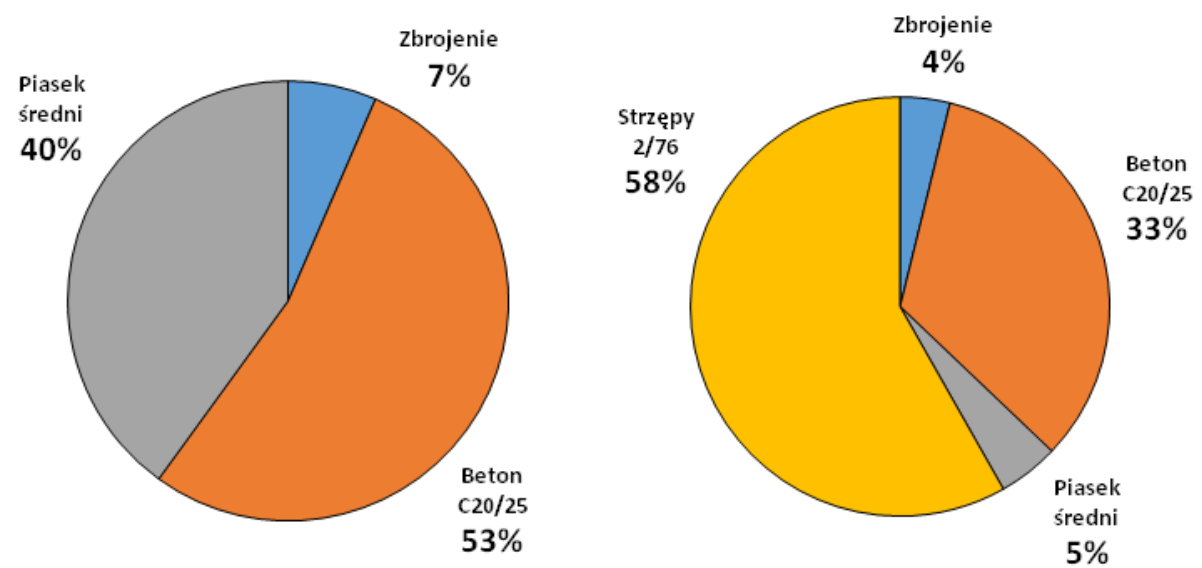

Rys.10. Udział materiałów w całkowitym koszcie nasypu z zasypką A i B.

\section{Podsumowanie i wnioski}

Z przeprowadzonych analiz wynika, że zastosowanie antropogenicznej zasypki $\mathrm{z}$ rozdrobnionych opon wpływa na zmniejszenie naprężeń $\mathrm{w}$ podłożu oraz pozwala ograniczyć wymiary konstrukcji oporowych. W efekcie daje to możliwość budowy lżejszych nasypów, które mogą być posadowione nawet na słabym podłożu. Aspekt ekonomiczny analizy obejmujący wyłącznie same konstrukcje oporowe okazał się w tym przypadku mało korzystny. Uznany za optymalny, wariant zasypki ze strzępami gumowymi (zasypka B) jest bowiem droższy o $28 \%$ od tradycyjnego rozwiązania z piasku (zasypka A). W przypadku występowania słabego podłoża, budowa lekkiego nasypu będzie jednak zawsze korzystniejsza zarówno technicznie i ekonomicznie ze względu na brak konieczności wzmacniania gruntu pod nasypem. Bezpośrednie porównanie oszczędności betonu i stali zbrojeniowej w konstrukcjach oporowych podpierających lekkie nasypy wskazuje, że w przypadku zasypki 
z gumą możliwe jest zapewnienie stateczności całej budowli przy zmniejszeniu kosztu betonu o 38\%, a zbrojenia o $43 \%$. Pokazuje to, że świadome podjęta i uzasadniona środowiskowo decyzja o zastąpieniu tradycyjnej zasypki z piasku antropogeniczną zasypką ze strzępów gumowych może przynieść sumaryczne oszczędności materiałowe na poziomie $40 \%$. Uwzględniając przy tym potrzebę coraz większej dbałości o ochronę środowiska, ponowne wykorzystanie gumy ze zużytych opon może mieć w tym aspekcie szczególne znaczenie. Należy się spodziewać, że w najbliższych latach zainteresowanie alternatywnymi sposobami budowy nasypów i konstrukcji oporowych z użyciem lekkich antropogenicznych zasypek gumowych będzie coraz większe. Konieczność stosowania się do obowiązujących dyrektyw unijnych może wymusić sytuację, w której w niedalekiej przyszłości wykorzystanie materiału ze zużytych opon będzie zjawiskiem nie tylko pożądanym, ale również opłacalnym, szczególnie w przypadku budowy lekkich nasypów na słabym podłożu.

\section{Literatura}

[1] Balunaini U., Yoon S., Prezzi M., Salgado R. Tire shred backfill in mechanically stabilized earth wall applications. Purdue Univ. West Lafayete, Indiana, 2009

[2] Bielańska J. Zastosowanie geokompozytów gumowych w budownictwie komunikacyjnym Praca dyplomowa mgr pod kierunkiem K. Trojnara, Politechnika Rzeszowska, 2016

[3] Duda A. Wybrane sposoby wykorzystania zużytych opon samochodowych. Journal of civil engineering, environment and architecture, 64 (4/17), 2017, 381-396

[4] Duda A. Trojnar K., Wykorzystanie zużytych opon samochodowych w budownictwie komunikacyjnym. Materiały Budowlane, 527, 2016, 80-82

[5] Drągowski A. Charakterystyka i klasyfikacja gruntów antropogenicznych. Przegląd Geologiczny, 9, 2010, 868-872

[6] Edeskär T. Technical and environmental properties of tyre shreds focusing on ground engineering applications. Luleå Univ. of Technology, Luleå, 2004

[7] EN 14243:2005. End-Of-Life Tyre, Recycling Materials. CEN Workshop Agreement, Brussels, 2005

[8] Glinicka M. Właściwości mechaniczne mieszaniny gruntu i odpadów z opon.

Budownictwo i Inż. Środowiska, 4, 2010, 99-104

[9] Gronowicz J., Kubiak T. Recycling zużytych opon samochodowych. Politechnika Poznańska. Problemy Eksploatacji, 2, 2007

[10] Hennebert P., Lambert S., Fouillen F., Charrasse B. Assessing the environmental impact of shredded tires as embankment fill material. Can. Geotech. Jour. 51, 2014, 469-478

[11] J\&B Recykling, www.jbrecykling.pl/, www.jbrecycling.co.uk/, 20016

[12] Meei-Hoan Ho, Ahmad Tarmizi, Chee-Ming Chan, Ismail Bakar, Leachability and strength of kaolin stabilized with cement and rubber. International Journal of Sustainable Construction Engineering \& Technology, vol. 2, 1, 2011, 89-104 
[13] Meei-Hoan Ho, Chee-Ming Chan, Ismail Bakar, One Dimensional Compressibility Characteristics of Clay Stabilised with Cement-Rubber Chips. International Journal of Sustainable Construction Engineering \& Technology, vol. 1, 2, 2010, 91-104

[14] Oikonomou N., Mavridou S., The use of waste tyre rubber in civil engineering works. In: Khatib J. Ed. Sustainability of construction material. 2009, 213-238

[15] PN-EN 1997-1 Projektowanie geotechniczne. Zasady ogólne. PKN, 2010

[16] Shrestha S., Ravichandran N., Raveendra M., Attenhofer J. A. Design and analysis of retaining wall backfilled with shredded tire. Soil Dyn Earthq Eng. 90, 2016, 227-239

[17] Sybilski D., Zastosowanie odpadów gumowych w budownictwie drogowym, Przegląd Budowlany 2009, 5, 37-44.

[18] Youwai S., Bergado D. Numerical analysis of reinforced wall using rubber tire chipssand mixtures as backfill material. Comp. and Geotech., 31, 2004, 103-114.

[19] Ustawa o odpadach z dnia 27 kwietnia 2001 r. (Dz. U. 2001, Nr 62, poz. 628)

[20] Ustawa z dnia 11 maja 2001 r. o obowiązkach producentów niektórych wyrobów oraz o opłacie produktowej i depozytowej (Dz. U. Nr 63, poz. 639 z późn. zm.)

\section{Zestawienie podpisów:}

Tabela 1. Europejska klasyfikacja rozdrobnionych opon

Table 1: European Classification of Shredded Tyres

Tabela 2. Parametry geotechniczne podłoża

Table 2: Geotechnical parameters of subsoil

Tabela 3. Parametry techniczne zasypki z piasku oraz ze strzępów gumowych

Table 3: Technical characteristics of filling materials; sand and rubber shreds

Tabela 4. Analizowane warianty wypełnienia nasypu

Table 4: Analysed variants of the embankment filling

Tabela 5. Koszty materiałowe nasypu tradycyjnego z piasku i alternatywnego z gumą

Table 5: Material costs of conventional sand and alternative rubber embankments

Rys. 1. Formy rozdrobnionych opon przydatne do wypetnienia nasypów; a. czipsy, b. strzępy.

Fig. 1. shredded tyre forms useful for filling embankments; a. chips, b. shreds

Rys. 2. Nasyp na dojeździe do wiaduktu w ciagu DK9 k/Rzeszowa

Fig. 2. Embankment on the access road to the DK9 viaduct near Rzeszów

Rys.3. Model numeryczny nasypu 
Fig. 3 Numerical model of the embankment

Rys.4. Stateczność na przesuw nasypu o różnej wysokości

Fig. 4: Stability on embankment movement of different heights

Rys. 5. Stateczność na obrót nasypu o różnej wysokości

Fig. 5: Stability per rotation of embankment of different heights

Rys. 6. Analizowane warianty wypetnienia nasypu $(A, B, C, D)$

Fig. 6: Analyzed filling variants of the embankment (A, B, C, D)

Rys. 7. Porównanie wyników analiz numerycznych nasypu z wypetnieniem tradycyjnym (zasypka A) i gumowym (zasypka B); a. osiadanie, b. naprężenia pionowe, $c$. naprężenia poziome, $d$. odksztatcenia

Fig. 7: A comparison of numerical analyses of the embankment with traditional (backfill A) and rubber (backfill B) fills; a. settlement, b. vertical stress, c. horizontal stress, d. deformations.

Rys. 8. Wyniki obliczeń dla różnych wariantów wypetnienia nasypów

Fig. 8: Calculation results for the various variants of embankment fill

Rys. 9. Porównanie kosztów materiałowych nasypu z zasypką A i B.

Fig. 9: Comparison of material costs of embankment with backfill A and B

Rys. 10. Udział materiałów w całkowitym koszcie nasypu z zasypka A i B.

Fig. 10. Percentage of materials in the total cost of embankment with backfill A and B 